\title{
Internet: de luces y sombras
}

\author{
Hernán Dinamarca \\ Doctorando Comunicación Organizacional: Universidad de Málaga, España. Email: \\ hernan.dinamarca@gmail.com
}

\begin{abstract}
Resumen: Hoy asistimos a un inédito desafío histórico y cultural: la imparable y acrítica expansión de las Tecnologías de la Información y las Comunicaciones (TIC), en tanto estas amplían nuestras capacidades mentales y comunicativas a límites aún insospechados. Ante la radicalidad de su impacto, el desafío es empezar a vivir las TIC de una forma responsable, creativa y crítica. Hasta ahora, en cambio, las hemos vivido deslumbrados ante sus luces y ciegos ante sus sombras. En el ensayo nos preguntamos tanto "¿qué hace una nueva tecnología?” como “¿qué también deshace?”. Buscamos entonces mediante una aproximación preliminar contribuir al debate acerca de los impactos existenciales, cognitivos, comunicativos y sociales de las TIC.
\end{abstract}

Palabras clave: TIC, comunicación digital, Internet, comunicación organizacional.

\section{Internet: On highlights and shadows}

\begin{abstract}
Today we are witnessing an unprecedented historical and cultural challenge: the relentless and uncritical expansion of Information and Communications Technologies (ICT), inasmuch as they extend our mental capabilities and communicative limits even unsuspected. Given the radical nature of its impact, the challenge is to start living ICT responsibly, creatively and critically. Until now, however, we have lived dazzle with their lights and blind to their shadows. In the essay, we ask both "what does a new technology build?" as well as "what as well does it unbuild?” Through a preliminary approach, we try to contribute to the debate about the existential, cognitive, communicative and social impacts of ICT.

Key words: ICT, digital communication, Internet, organizational communication.
\end{abstract}

\section{Internet: luzes e sombras}

Resumo: Hoje nós estamos testemunhando um desafio sem precedentes históricos e culturais: a expansão implacável e acrítica de Tecnologia da Informação e Comunicação (TIC), como estes estendem nossas capacidades mentais e comunicativas a limites mesmo insuspeitos. Dada a natureza radical de seu impacto, o desafio é começar a viver a TIC de maneira responsável, crítica e criativa. Até agora, porém, temos vivido deslumbrados com as luzes e cegos às suas sombras. No ensaio, nos perguntamos tanto por "o que faz uma nova tecnologia” como "o que também cai”. Então nós olhamos através de uma contribuição preliminar para o debate sobre os impactos existencial, cognitivo, comunicativo e social das TIC. organizacional.

Palavras-chave: TIC, media digital, Internet, comunicação 


\section{Un desafío histórico y cultural: ¿cómo vivir con las TIC?}

Las Tecnologías de la Información y la Comunicación (TIC) en las últimas décadas se han expandido de manera vertiginosa. El hecho es de un impacto existencial (y uso este concepto por sus implicancias aún abiertas en la vida individual y social) con pocos precedentes en el devenir de la cultura, tal vez la introducción de la herramienta, tal vez la imprenta, podrían servir como analogías históricas.

Sin duda se trata de una revolución, pues las TIC subvierten todas nuestras prácticas y miradas. El cuerpo y corazón de las TIC, la Red de redes que es Internet, metafóricamente podría describirse como un omnicerebro de la diversidad y complejidad humana. He aquí un solo dato, que evoca misterio por lo demás, a la actual tasa de expansión de Internet para el año 2.019 se proyectan 1.000.000.000.000.000 de interconexiones electrónicas de computadores (Vídeo Futuro de Internet, 2009. www.youtube.com). La extraordinaria cifra es similar a la cantidad de sinapsis neuronales -interconexiones también eléctricas que potencialmente ocurren entre las células del cerebro de un individuo de la especie. Y este es precisamente el potencial cultural más asombroso e inasible abierto por las TIC en la deriva del ser humano: que ambas macro-sinapsis a la vez se encuentran entre si en sinapsis cibernética: esto es, que el cerebro humano se retroalimenta (cambia en consecuencia) con el omnicerebro que es la Red Internet.

La tecnología como extensión y prolongación de nuestros cuerpos y sentidos ha sido el sueño cultural más logrado en el devenir de hombres y mujeres. En occidente, uno de los ejes del paradigma social moderno fue poner la racionalidad científico instrumental al servicio expreso de las aplicaciones tecnológicas: de ahí el singular poder expansivo de la técnica. Tanto poder, que a finales de la modernidad hemos explorado el microcosmos y macrocosmos y con las TIC estamos ampliando nuestras capacidades mentales y potencialidades comunicativas a límites aún insospechados.

En ese marco conceptual, es sugerente la interpretación que hace Joan Mayans i Planells en su ensayo "Metáforas Cyborg" acerca de dos películas fundamentales para entender la expansión tecnológica de las últimas décadas. Escribe: "Blade Runner desafiaba la frontera de lo intrínsecamente humano y The Matrix jugaba con la frontera de lo intrínsecamente real” (Mayans i Planells, Joan, 2002). Y claro, si la tecnología es la extensión de los sentidos, las TIC sin duda amplían el campo de profundidad y comprensión de lo que es y puede llegar a ser lo humano. Por ejemplo, con la biotecnología -y es la metáfora de los androides en Blade Runner- lo humano potencialmente podría ampliarse, así como con las TIC; y en la metáfora de The Matrix, lo real es lo virtual y lo virtual es lo real. Tan real es el ser humano como lo es el ser animado virtual, tan real es el individuo orgánico como su avatar, pues ambos están e inciden en el mundo. Lo Real, pos TIC, incluye lo real tradicional y lo real virtual. 
Las TIC emergen de la organización humana y hoy son parte constitutiva de la misma. Lo son en la familia, en las empresas, en todo tipo de instituciones, estados, comunidades y en las redes planetarias. Una sumaria descripción de las organizaciones nos revela que éstas son sistemas y personas con sus emociones, pre-juicios, cuerpos y memoria-historia, cuya estructura son las partes en una interacción dinámica que es condicionada y condiciona al todo organizado; las organizaciones son colaboración, ya que más allá de la realidad de la competencia, sin una activa cooperación diaria entre los sujetos las organizaciones se autodestruirían; finalmente son comunicación, que es el acto de dejarse sentir unos a otros, en tanto toda organización debe poner en común lo que es su propósito: un objetivo compartido. ${ }^{1} \mathrm{Y}$ este último ámbito, las comunicaciones, -que es el corazón de las organizaciones- es el que está siendo subvertido por las TIC. Ergo, si las TIC revolucionan las comunicaciones, lo subvierten todo en las organizaciones: a las personas, al sistema, a la cooperación y a la competencia.

Por eso, ante la radicalidad de su impacto, el núcleo del actual desafío cultural a que asistimos es empezar a vivir la expansión de las TIC de una forma reflexiva, responsable y crítica. Lo escribo así, porque hasta ahora, inmersos aún en una cultura que ha mitificado a la técnica (como lo ha sido la sociedad moderna occidental), la nueva experiencia que nos traen las TIC la hemos vivido en una fascinación acrítica, deslumbrados antes sus luces y ciegos ante sus sombras.

Neil Postman, ex Director del Departamento de Cultura y Comunicación de la Universidad de Nueva York, ha resumido notablemente este problema y desafío socio-cultural. En su "primera advertencia” sobre el cambio tecnológico, escribe que "todo cambio tecnológico implica un trato faustiano. La tecnología da y la tecnología quita. Quizás la mejor manera de expresarlo sería diciendo que la pregunta “¿qué va a deshacer esta nueva tecnología?” es igual de importante que la pregunta "¿qué va a hacer esta nueva tecnología?” (Postman, Neil, 2004a).

Esta pregunta, pese a su seriedad, hoy casi nunca es formulada. Y es urgente y necesario empezar a hacerlo. No podemos sustraernos de nuestro libre albedrío y conciencia. Es una responsabilidad humana el por qué, el cuánto y el cómo ampliamos nuestros sentidos, es decir, cómo usamos la tecnología. Haciendo una analogía con la revelación que nos han hecho todas las tradiciones espirituales y también el sicoanálisis -que cada hombre y mujer somos en unidad una luz y una sombra que nos acompaña-, hoy podemos afirmar que las TIC, en ambigua unidad, conllevan sus propias luces y sombras. El omnicerebro que es Internet, al igual que el cerebro humano, tiene su luz y su sombra. De ahí, reitero, que el desafío humano es vivir en organizaciones que se hagan cargo responsablemente de esta complejidad intrínseca a las TIC.

Este ensayo busca contribuir a este incipiente, al menos en la esfera pública, y necesario debate. Lo escrito hasta ahora es el problema. En el apartado 2 intento una caracterización histórica y general de las TIC, así 
como algunas sombras de su vertiginosa expansión; en el 3 abordo los ecos existenciales de las TIC y en el 4 sus impactos políticos y sociales, siempre con sus luces y sombras; y en el apartado 5, a manera de epílogo, concluyo con algunas reflexiones sobre el actual desafío cultural ante esta ambigüedad implícita en las TIC.

\section{El reciente y expansivo devenir de las TIC}

Las TIC son igual a informática, telecomunicaciones y tecnologías audiovisuales. Las TIC configuran una sociedad caracterizada por el uso extensivo de éstas y por su integración operacional, en tanto toda la información tiende a confluir a la pantalla del computador y lo hace en un mismo código o lenguaje digital (en bit, que es una contracción del inglés binary digit: es la unidad, pedazo, trozo, que designa la cantidad elemental de información: 0 ó 1 en lenguaje digital.

Las TIC están imbricadas dialécticamente con otras dinámicas centrales y tendencias conductuales de la sociedad contemporánea. Enumero algunos ejemplos. Primero, son un efecto de la ciencia, pues son tecnologías que derivan de las aplicaciones científicas, y son una causa, pues aceleran la evolución de la ciencia con sus enormes posibilidades de manipulación e intercambio de información. Segundo, son causa del proceso de globalización, en tanto su rol central en las dinámicas de intercambio informativo y económico planetario, y son un efecto, ya que necesariamente se expanden debido al proceso de globalización. Tercero, son paradójicas, pues aumentan en forma inconmensurable los flujos de información, pero a la vez la saturación genera “ceguera informativa” (los árboles no permiten ver el bosque) y también dejan obsoletos algunos conocimientos y debilitan el ideario de la sabiduría humanista. Cuarto, revolucionan el pensar y el lenguaje, pues traen nuevas maneras de pensar y nuevas hablas y eliminan otras. Quinto, subvierten emociones y valores, pues potencian unas e inhiben otras. En suma, las TIC inciden en todos los aspectos de la vida individual y social: instauran una red en el trabajo humano, una red intra-organización y una red entre organizaciones, alteran el ocio y el arte, e impactan en nuestras relaciones, en la percepción del mundo y en el pensar. Las TIC se imbricaron en nuestras vidas (luego en el apartado 3 y 4 ampliaremos estos conceptos).

La tendencia, como dije antes, es hacia la integración de las TIC en la más revolucionaria de sus propias creaciones: la red Internet que sobre la base de las interconexiones de computadores permite acumular y manipular todo tipo de información. Internet es la sociedad humana en red.

Internet, como casi todas las grandes creaciones e idearios humanos que hoy nos impactan, se desarrolló a partir de los años setenta del siglo XX. ${ }^{2}$ El antepasado de Internet es el Arpanet creado en 1969 por iniciativa del Ministerio de Defensa de Estados Unidos. En estas reflexiones que tratan sobre cómo asumimos creativa y responsablemente esta nueva expe- 
riencia -porque eso es la Red de redes- es conveniente destacar que en términos históricos estamos hablando de un hecho tecnológico extraordinariamente reciente.

Con posterioridad a 1969, la Red fue desarrollándose al ritmo de una dinámica interactiva entre la investigación científica y tecnológica universitaria, los programas de investigación militar de los Estados Unidos y la contracultura radical libertaria de los años sesenta. Esta última, menos pragmática que las dos primeras, en el proceso fue propiciando un instrumento con mayor autonomía en relación al Estado y las grandes empresas, lo que hasta la fecha ha determinado en gran medida su arquitectura de gestión basada en la libertad de acceso y la cooperación. (En paréntesis, este modelo libertario fue en última instancia el cuestionado recientemente con el acoso desde el poder al sitio WikiLeaks, tras la publicación de cables diplomáticos de Estados Unidos. Por eso de inmediato se desató la primera guerra informática entre el antiguo orden establecido versus la nueva cultura que nació de las TIC. Ante el intento del poder económico y politico -algunas grandes empresas y gobiernos- por expulsar de la red al sitio, los internautas de la transparencia, los hackers activistas -autonominados Anonymous- iniciaron la «Operación Venganza» contra los sitios de PayPal, MasterCard, Visa y Amazon, empresas que habían cerrado las cuentas de WikiLeaks. "Estamos tratando que Internet se mantenga como un lugar libre y abierto, como siempre ha sido. El problema es que en los últimos meses y años hemos visto cómo los gobiernos están tratando de coartar nuestra libertad en Internet», aseguró en esos días a la prensa el profesor de sistemas de información en la IE Business School de Madrid, Enrique Dans”) (Fuente BBC Mundo)

A finales de los ochenta e inicios de los noventa se inicia el uso socialmente expansivo de la Red. La miniaturización creciente del hardware (equipos) y la creación y comercialización masiva de software (programas y sistemas operativos que perfeccionan y uniformizan la interfaz gráfica, además del e mail y la Web) fueron consolidando a estas nuevas máquinas-cerebros programables. La seducción que empezaron a ejercer sobre sujetos y organizaciones fue imparable: cómo no, si pueden hacer tantas cosas en un “diálogo” virtual con el ser humano, con quien juegan, trabajan o le ayudan en complejas tareas expertas.

Hoy ya todo confluye al ciberespacio, una realidad virtual en red, cuya ubicuidad es en el éter, casi inmaterial. Una Red portadora de una comunicación digital que en simultáneo esta en todas partes e integra a todos los signos (escritura, sonidos e imágenes) en el hipermedia, en el hipertexto, y además en interactividad entre sus medios -máquinas, los programas y el ser humano. Recién escribí casi inmaterial, ya que en rigor la red está formada por líneas telefónicas, analógicas o digitales, por fibras ópticas de un micrón de diámetro, por cables, por satélites. Como se lee, la red inmaterial es también material, concreta, y a lo largo de tales materiales, bajo los mares y en los cielos, circulan paquetes de bits. 
Antes de continuar, precisemos algunos conceptos que hoy son de uso cotidiano. Primero, Internet cuenta con el sistema de direcciones global de los protocolos de comunicación TCP/IP (Transmisión Control Protocol/Internet Protocol). Segundo, Internet en rigor es extranet e intranet. Extranet es la red de redes (es lo que solemos llamar Internet), protocolizada, que se hace y rehace. Intranet, con igual protocolo, es una red siempre acotada, intra a una organización. Claro que como el límite entre extranet e intranet es difuso y móvil, los analistas prefieren hablar sólo de Internet. Las intranets, redes no globales, están siempre limitadas al interior de una empresa, una ONG, un municipio, universidad, por ejemplo; pero suele estar enlazada con extranet (Internet), se puede “salir” por decirlo de alguna manera, lo que suele no ocurrir es que se pueda ingresar desde “afuera”, desde la Red de redes, a la intranet.

\section{Algunas cifras sobre su desigual e imparable expansión}

Al finalizar la primera década del siglo XXI, la población mundial ronda los 7.000 millones de personas y la expansión de las TIC sigue a gran velocidad en todas las geografías y en todos los ámbitos de la vida social. El abaratamiento de los productos tecnológicos y su carácter cada vez más amigable para el usuario, facilita la expansión de las TIC en todos los sectores socio-económicos y culturales. Sin duda, asistimos a su masificación (lo dicen las cifras), pero también este proceso aún es geográfica y socialmente desigual (también lo muestran las cifras). Veamos.

Según la consultora especializada Forrester Research, la cantidad de computadoras utilizadas en el mundo el año 2008 superó los mil millones de unidades. Llevó 27 años llegar a esa cifra, pero en sólo otros cinco se llegará a los dos mil millones. ${ }^{3}$

El mismo 2008, el porcentaje de los hogares con conexión a Internet alcanzaba a un 94,1 en Corea, un 82,9 holanda, un 78,5 Suecia, mientras que en el otro extremo Turquía llegaba a un 1.7 por ciento. La mayoría de los países evaluados (aproximadamente 40 con economías medianas y grandes) oscilaban en un rango entre 61.7 en USA, 55.7 promedio para los países de la OCDE y 44.5 España.

La Unión Internacional de Telecomunicaciones (UIT), una agencia técnica de la ONU, indica que 23 de cada 100 personas en el mundo utilizan la red, aunque la llamada «brecha digital» es muy clara, pues mientras los usuarios de esa tecnología en Europa y América como promedio superan el 40\% de la población, en Asia es cerca del 15\% y en África es menos del 5\%. La misma UIT informa que en el mundo hay 4.000 millones de suscripciones a la telefonía móvil, pero en África abarca sólo a un $28 \%$ de la población, en Asia al 38\%, en América el 72\% y en Europa el 111\%.

El Foro Económico Mundial ha venido midiendo desde hace años cómo los países aprovechan las oportunidades que brindan las TIC. En el análisis consideran el entorno, que mide el grado en que el ambiente gene- 
ral del país fomenta el desarrollo de las TIC; la preparación, que mide el grado en que los agentes (individuos, empresas y gobierno) están preparados y se interesan en las TIC; y el uso, que mide el grado en que los agentes utilizan activamente las TIC en términos de productividad y eficiencia. El Ranking Global de Tecnologías de Información 2009 - 2010 midió a 133 países de todo el mundo, quedando como líderes Dinamarca, Suecia, Estados Unidos y Singapur, en una posición de desarrollo avanzado a intermedio se encuentran países como Chile (40 en el ranking) India, Colombia, Grecia y Brasil (60), y entre los países de menor desarrollo de las TIC aparecen Bolivia Etiopia, Zimbabwe, Chad, Paraguay, Nicaragua, Cambodia y Nepal.

Como lo indican las cifras, co-existen las luces de la expansión con una doble sombra. Primero, la sombra de la desigualdad social en el actual acceso, cuya proyección en el tiempo debería ser a la inhibición de continuar la tendencia a la democratización o masificación en el acceso a las TIC. Segundo, una sombra que adquirirá cada vez más presencia en el futuro, me refiero a la barbarie en el uso o el hecho que las desigualdades se continuarán expresando en cuanto a alfabetización digital y aprovechamiento de las potencialidades de las TIC. Seguramente los países con mejor Índice de Desarrollo Humano, según la conceptualización que hace el PNUD ${ }^{4}$ aprovecharan mejor las luces de las TIC, mientras los países con menor Desarrollo Humano serán más impactados con sus sombras (esta línea de busqueda investigativa es interesante, por ahora -sobre la base de simples observaciones- intuyo que al menos en Europa el uso de las TIC es más reflexivo y sereno que en los países del sur, que imitan a destajo y que están obnubilados con las TIC, Chile más que otros incluso). Eso a nivel comparativo entre estados-naciones. E intra-naciones, la desigualdad de uso también tenderá a alinearse con las desigualdades sociales y educativas.

\section{Ecos existenciales de las TIC}

Con las TIC, en especial con la Red de redes, asistimos a un cambio radical en la manera de generar sentidos (recordemos que cada texto, cada bit codificado de información, es un sentido para quién lo decodifica desde su propio sentido), en la manera de acumularlos, de distribuirlos y de reflexionar y pensar sobre ellos. En consecuencia, se trata de un impacto intenso en la conciencia humana, por ello le califico de existencial.

La red Internet, en la actual transición histórica modernidadposmodernidad, está implicando un impacto vital tan intenso como lo fue la extensión de la imprenta durante la transición Edad Media-Época Moderna. Igual que ayer la subversión de la imprenta nos permitió interconectarnos más y cambiar la mirada, hoy la subversión de Internet, interconectándonos más aún, nuevamente nos lleva a cambiar, acelerar y multiplicar nuestra mirada.

Cuando Marshall Mc Luhan intuyó que "el medio es el mensaje” nos invitaba a comprender que cualquier tecnología que actúa como medio 
y/o como soporte comunicativo impacta nuestros cuerpos, nuestras mentes y emociones. Cualquier tecnología comunicacional, al codificar y decodificar el mundo, siempre abre y/o cierra mundos. "El cambio tecnológico no es aditivo, es ecológico. Un nuevo medio no añade algo, lo cambia todo... después que se inventara la imprenta, no teníamos la vieja Europa más la imprenta, teníamos una Europa diferente.” (Postman, Neil, 2004b).

Otro pensador, Jeremy Rifkin, en su última obra, Civilización Empática, nos recuerda que la imprenta conlleva el pensamiento lineal que es distinto al pensamiento de la cultura oral- en la evolución de la conciencia humana y también conlleva el fortalecimiento de la noción de individuo autónomo, rasgo tan propio del sujeto moderno, en tanto el vínculo entre lector y libro es íntimo e individual -acto que es distinto al vínculo siempre colectivo propio de la cultura oral que precedió a la imprenta. Mientras en el ámbito socio-económico - institucional, sin la imprenta y sólo con "los códigos antiguos y las formas orales de la comunicación habría sido imposible organizar el espectacular aumento del ritmo, la velocidad, el flujo, la densidad y la conectividad de la actividad económica basada en la maquina de vapor alimentada con carbón” (Rifkin, 2010), todas características constitutivas de la sociedad moderna que emergió con la revolución industrial, así como habría sido históricamente imposible el cambio cultural asociado a las prácticas democráticas, la extensión de la escolaridad y la expansión de los conocimientos.

Lo mismo ahora, después de las TIC, ya no habitamos el mundo que teníamos antes de los sesenta del siglo XX, sino que desde ahí poco a poco emergen un conjunto de signos, entre otros las TIC con su revolución en las comunicaciones, que a muchos autores que observamos y reflexionamos sobre el presente como Historia nos permite afirmar que estamos viviendo un cambio de época histórico y un cambio cultural con ecos cualitativos, por lo que empezamos a habitar un planeta diferente, posmoderno en términos históricos, en el sentido de ser distinto a la cosmovisión hegemónica en la época histórica moderna. ${ }^{5}$

Como ya hemos dicho, es radicalmente nuevo que con las TIC por primera vez tenemos una especie enredada como nunca antes en un omnicerebro de interconexiones electrónicas, una red de millones de redes de computadores en las que trafican desde las transacciones financieras y comerciales, son regulados los transportes y se cobijan las palabras, las imágenes y las emociones de hombres y mujeres en todas las lenguas. La red como la materialización de la Torre de Babel.

Con las TIC las interacciones humanas ya no sólo ocurren en la naturaleza o espacio físico (que era el lugar hegemónico de la sociedad agraria), ni tampoco sólo en el espacio de la polis (que era el lugar hegemónico de la sociedad industrial), sino que ahora se agrega el espacio virtual de la Telepolis o Tele-naturaleza que han creado las telecomunicaciones: una nueva sociedad de la velocidad y de la información, cuyo lugar hegemónico esta en todas partes, en una virtualidad 
cuyo mejor símbolo es la TV o pantalla del computador como la nueva plaza pública. ${ }^{6}$

\section{Las luces del omnicerebro Internet}

\section{La Red nos interconecta en la memoria y en el acto}

Si la tecnología es la prolongación de lo humano, así como las máquinas ampliaron nuestras capacidades físicas, las TIC amplían y cambian nuestras capacidades mentales.

Lo que hizo la imprenta fue sistematizar y extender por escrito el habla y el pensamiento, dotó a la humanidad de una mayor memoria y con la escritura reflejó en el papel blanco una manera lineal de pensar; hoy, por su parte, la red Internet es la síntesis de todos los medios precedentes para transmitir sentidos, incluida la palabra escrita y la palabra audiovisual, pues toda comunicación es siempre codificada y decodificada en última instancia por la Palabra -el sentido. La red nos inunda con toda la memoria de la especie y en simultáneo nos otorga una portentosa interconexión. La memoria y la instantaneidad del omnicerebro que es Internet opera como un "banco" planetario del código transgenético que en los hechos es el Lenguaje - Palabra para los individuos de la especie humana.

Para entender mejor esta analogía biológica quiero recordar aquí lo que ocurre genéticamente en ese reino de creatividad y cualidades evolutivas que son las bacterias. Las bacterias (los seres vivos más abundantes y más aptos en sobrevivencia) poseen una impresionante creatividad evolutiva: unos "individuos a otros", en una red global de intercambio genético (su propia "Internet biológica"), se pasan libremente rasgos hereditarios con un poder y una eficiencia increíble. Lynn Margulis y Dorion Sagan lo describen así: «en los últimos cincuenta años los científicos han observado que las bacterias transfieren rápida y rutinariamente distintos bits de material genético a otros individuos. Cada bacteria dispone periódicamente del uso de genes accesorios, provenientes en ocasiones de muy diferentes linajes y que cubren funciones que quizás su propio ADN no podría desarrollar... Como resultado de esta habilidad (recombinación de ADN), todas las bacterias del mundo tienen acceso a un único banco de genes y por ende a los mecanismos de adaptación de todo el reino bacteriano. Según el bacteriólogo Sorin Sonea, estrictamente hablando las bacterias no deberían ser clasificadas en unas y otras especies, pues todos sus linajes pueden potencialmente compartir rasgos hereditarios y cambiar hasta un 15\% de material genéticos en un día.” (Margulis, Lynn - Sagan, Dorión, 1992).

¿Por qué esta larga cita sobre la creatividad evolutiva de las bacterias? Porque su red planetaria de intercambio de información genética podría perfectamente compararse con la red planetaria -que ahora es Internetde intercambio de bits con información de nuestra memoria-lenguaje. Desde que habitamos en nuestra única morada (el lenguaje, según Heidegger), siempre hemos contado con la creatividad evolutiva que nos otorga nuestro 
código transgenético (las palabras) para recombinar experiencias entre los individuos de la especie (pues la información es experiencia suspendida en las palabras). Lo inédito del presente es que con Internet ese intercambio se potencia hacia atrás y en el acto, recombinando nuestras experiencias de una manera aún impensada y que podría acelerar de manera también aún impensada nuestra creatividad evolutiva.

Sobre la base de esta comprensión de Internet como memoria planetaria de la humanidad, la Ley de Robert Metcalfe es sobrecogedora: $\mathrm{P}$ $(n)=n 2$. P es potencia y n es la Net (la Red.) Metcalfe presentó esta fórmula en 1973, en su tesis doctoral para Harvard. Un ejemplo de la Ley de Metcalfe: 400 computadoras en red tienen el poder de 400 x 400 y no de $390+1$. Es decir, cada usuario dispone de 160 mil aparatos y sus programas. Cuando su PC está en Internet su disco duro es la red. Cada usuario que se conecta tiene bajo la punta de sus dedos la totalidad de los programas y poderes de los millones de computadores entrelazados. Más allá del debate en la comunidad científica sobre si la Ley de Metcalfe sobreestima el valor de las conexiones añadidas (tesis de Andrew Odlyzko y Benjamin Tilly ) o si las subestima, que es la tesis de la Ley de Reed, de David P. Reed, ${ }^{7}$ lo inequívoco es que a disposición del usuario de Internet se encuentra todo el conocimiento humano y la capacidad de crear con él. Como hemos reiterado, la Red, por llevar y distribuir todos los sentidos, todos los lenguajes, es y será cada vez más la memoria global de la humanidad.

\section{La Red favorece una nueva manera de pensar integrativa}

También de consecuencias evolutivas insospechadas resulta el hecho que la interfase de la pantalla del computador es no lineal. A la memoria de la red Internet cada uno de nosotros accede a través de un proceso de interconexiones simultáneas. Esto no es trivial, pues progresivamente debería implicar un cambio cualitativo en las nuevas generaciones que están aprendiendo a pensar con las TIC, ya que la simultaneidad, la interfaz gráfica y el hipertexto favorecen una nueva manera de pensar integrativa, sistémica, no lineal, que podría estar mejor preparada para lidiar con la complejidad real del mundo.

Por lo mismo, a diferencia del pensar lineal -causal y de izquierda a derecha-, propio de la época histórica moderna, que emergió y se ha desarrollado junto a la imprenta, la nueva manera de pensar que anuncia Internet y que ya se aprecia embrionariamente en las nuevas generaciones, es cada vez más no lineal, integrativa y sistémica, en ese sentido más emparentada con la cultura oral -no lineal- que con la cultura escrita -lineal-.

Claro que lo potente, inédito y desafiante en este nuevo escenario histórico, es que con Internet es posible -si acaso asumimos con sabiduría sus luces y sombras- contener lo mejor de ambas culturas, de nuestra memoria, la oral y escrita, cuya mejor síntesis son las potencialidades audiovisuales que la red ofrece. 


\section{Las sombras del omnicerebro Internet}

Como escribimos antes, cualquier tecnología conlleva su propio perjuicio. Por ejemplo, si en una cultura oral -a través de proverbios, refranes y canciones- se mantenía y transmitía la sabiduría de una comunidad, obviamente que allí el ejercicio de la memoria era relevante al menos entre los sujetos portadores de esa sabiduría. En cambio, en la era de la imprenta, en desmedro del ejercicio de la memoria, pues ya no se memorizan los proverbios, refranes y canciones, sino que se escriben, se otorga mayor relevancia a la organización lógica y al análisis sistemático. Como se lee, la riqueza del ejercicio de la memoria en la cultura oral es perjudicado en la cultura escrita, que conlleva sin embargo otras fortalezas. Asimismo hoy, Internet junto a sus luces, conlleva potenciales perjuicios -por sus sombras- a lo que eran fortalezas de antiguas formas de comunicación.

\section{La eventual pérdida de la sabiduría}

En tanto vivimos en una relación y estado de ánimo acrítico con las TIC, no nos cuestionamos mayormente que las personas hoy tienden a valorar más la velocidad.

Entre las nuevas generaciones, en la comunicación todo debe ser rápido, instantáneo, breve, desdeñan el silencio de la espera, la introspección, la calma reflexiva y la exposición serena de los argumentos. Tanto así que en países como Chile incluso la política -que es la reflexión y acción sobre la res (cosa) pública-, hoy (¿empobreciéndose?) encuentra un espacio preferencial en Twitter y sus 140 caracteres.

Con las TIC, hoy las personas valoran más lo inmediato, el aquí y el ahora, desdeñando la memoria y los hechos históricos.

Con las TIC se valora la masificación y la instantaneidad de la información, el dato específico, la información especializada y acotada a un determinado dominio del conocimiento. En suma, se valora más la información cuantitativa del árbol que el conocimiento cualitativo del bosque.

De esa manera, con las TIC la sabiduría es cada vez más un concepto menos valorado y podría llegar a desaparecer. Si consideramos que en la vida práctica siempre la sabiduría ha sido considerada sinónimo de la prudencia que surge de una inteligencia aplicada, que se desarrolla con la experiencia, con la memoria activa y de largo plazo, dada por el conocer los antecedentes y la historia de cualquier deriva, y que es lo opuesto a la ausencia de reflexión, aquella aceleración atropelladora que linda con la tontera; es obvio entonces que debido a la actual sobrevaloración de algunas cualidades de las TIC -como la velocidad y lo instantáneo-, éstas podrían estar contribuyendo a una valoración cada vez menor de la sabiduría, cualidad tan relevante en todas las anteriores sociedades humanas. 


\section{La sombra de la libertad de nuestra sombras en Internet}

Cuándo algunos miran de soslayo u horrorizados los riesgos morales y los peligros a la integridad de niños y niñas en Internet, causados por sitios pornográficos a la mano de todos o por las redes sociales que pueden usar pedófilos para "seducirles", o bien cuando otros con pose autoritaria cuestionan la libertad en la red para que quien quiera emita lo que quiera en su seno, o bien terceros observan con ajena distancia la posibilidad de suplantaciones de identidad, de generar olas de rumores y de mentiras en la red; casi nunca nos detenemos a reflexionar que esas potenciales sombras éticas están profundamente imbricadas con nuestra propia sombra. Me explico, la libertad de Internet no puede ser de otra manera si llevamos hasta las últimas consecuencias lo que en este ensayo hemos reiterado: que Internet es lo más parecido a un supra-cerebro humano, con sus luces y sombras.

Si la Red todo lo cobija, si es la memoria global de la humanidad y es también su mega-conciencia en acto, pues bien, siendo así, obviamente que la Red no puede dejar de ser un reflejo-espejo de la propia complejidad del cerebro y de la conciencia humana, con sus luces y sombras. Como nos interpela el poeta Nicanor Parra en su célebre Autorretrato: cada uno de nosotros, hombre o mujer, somos “un embutido de ángel y bestia”, luego es imposible que entre los pliegues de cada bit en la Red no asome también la bestia co-existiendo siempre con el ángel.

Si queremos continuar con lo que hasta ahora han sido las más iluminadoras luces de la red -su libertad de acceso y creatividad, su memoria-totalidad, su potencia para el saber y el conocer-, tendremos que aprender a lidiar con responsabilidad con su sombra. Precisamente en esa tensión se juega una vez más la libertad de cada uno, el buen juicio y la sabiduría; nuestra responsabilidad radica en lo que queramos potenciar y usar, ya sea la luz o la sombra, en cómo enseñemos a las nuevas generaciones a vivir en y con las TIC, cómo, igual que en la vida y en nuestra interioridad, aprendemos a optar en la humana ambigüedad que proyectamos en la Red. La sombra de Internet y de las TIC es la proyección de nuestras propias sombras, por eso el desafío evolutivo una vez más se nos devuelve al interior de cada uno.

\section{La pérdida de la riqueza del lenguaje escrito}

Con las TIC ocurre una pérdida que es ya evidente en las nuevas generaciones. La cultura escrita, junto al pensar lineal, nos otorgó la disciplina de la forma alfabética, el rigor de la sintaxis y la bella ambigüedad de la semántica. El lenguaje, si bien evolucionaba con el habla, se reproducía bajo el respeto de esos códigos formales y semánticos.

Hoy en cambio, el hipertexto, la velocidad y el ensimismamiento que conlleva el habla virtual y no lineal del chat en las TIC, por ejemplo, pese a ser escrita en el teclado del computador o del teléfono celular, siempre degrada la forma alfabética, corrompe la sintaxis y por carencia de 
estilo tiende a veces a eliminar la ambigüedad (cuando lo breve se une con la escasez de sentidos) y en otras a aumentarla con un "ruido semántico" que puede alcanzar niveles críticos (cuando lo breve y la velocidad se unen con la exigencia de riqueza de sentidos).

De esta manera, en una observación crítica surgen varias preguntas: ¿será necesariamente la evolución en las TIC sinónimo de pérdida de la tradicional riqueza del lenguaje escrito y hablado? ¿Debemos sólo observar pasivamente esa pérdida potencial, o bien promover la oralidad y lo audiovisual que permiten las TIC, pero sin renunciar al rigor, la riqueza y disciplina sistemática específica que nos ofrecía la cultura del lenguaje escrito? Son preguntas que sin duda hay que hacerse a la hora de reflexionar respecto al uso de las TIC en las organizaciones (en especial en las empresas, las escuelas y en el hogar).

\section{La sombra de la desmesura informativa que narcotiza y desinforma}

La simultaneidad, instantaneidad y la desmesura de contenidos en las TIC nos amenazan con la sombra del exceso de información que cada día resulta más difícil de procesar. Sabemos que en el vivir cotidiano más información genera mayor confusión, puesto que la desmesura inhibe la capacidad de análisis de la información. Se ha convertido ya en un lugar común hablar de intoxicación informativa y de su contraparte, la ansiedad por informarse. Ambos excesos van juntos: son tantos los estímulos informativos que intentamos ansiosamente linkearnos con todos, generando a la vez angustia y vacío en una dialéctica emocional muy nociva.

Según Rescue Time, una compañía privada con sede en Seattle y dedicada a la producción de software e investigaciones sobre TIC, el estrés de quienes trabajan en una computadora lleva a que revisen su bandeja de correo electrónico cada vez que suena la llamada auditiva o al menos 50 veces cada día laboral. Algo aún más ansioso ocurre con los teléfonos inteligentes, hoy se suele llamar con el anglicismo crackberries a quienes son incapaces de dejar de enviar y recibir mensajes, por lo que lo hacen compulsivamente en una reunión, en una cena familiar, en el cine e incluso en lugares tradicionalmente más íntimos.

Es un hecho fácil de reconocer en nuestras interacciones cotidianas que el exceso de estímulos informativos genera estrés y aturdimiento. Más grave todavía: hoy aumenta la investigación analítica que da cuenta que el exceso de mensajes breves a través de las redes sociales en las TIC, junto a la paradoja que disminuye la capacidad de lectura, pese a la abundancia de lectura disponible, también está inhibiendo el discernimiento moral que ha sido lo propio de la colaboración y las más altruistas decisiones humanas.

En mi opinión, una consecuencia dramática de esta realidad, por ejemplo, es la inconsistencia entre el exceso de información en la Red acerca de la inminencia de un ecocidio debido al actual cambio climático por presiones antrópicas, pero paradojalmente es una irresponsabilidad suicida 
la carencia de acción eficaz y masiva al respecto, tanto en la mayoría de los gobiernos como en la mayoría de la sociedad civil, aturdidos todos en el día a día del crecimiento económico. ${ }^{8}$ Hay una inconsistencia entre la gravedad de lo que sabemos inminente, con su consecuente urgencia por actuar, versus la apatía social, pese a lo dramático del hecho. Ese y muchos otros ejemplos dan cuenta de lo que los teóricos pioneros en la reflexión sobre el impacto de los medios masivos, Paul F. Lazarsfeld y Robert K, Merton, allá a finales de los sesenta denominaron Disfunción Narcotizante, esto es, que el exceso de información instantánea y sin contexto interpretativo, que sólo busca el sensacionalismo y conmover frívolamente al receptor, termina logrando lo contrario: narcotizar, no informar, no generar reflexión ni menos impulsar a la acción. Lo que los autores identificaron como una tendencia en los primeros Media electrónicos (Radio y TV), hoy se ha visto expandido por las TIC. (Discutible, con los años, es lo que Lazarsfeld y Merton se ocuparon ayer en aclarar: que usaban la expresión disfunción, y no función, porque partían de la premisa que no había voluntad entre los gestores de los Media ni en la sociedad de que este efecto narcótico fuera una función aceptada de los medios masivos. Digo discutible porque si bien no creo en conspiraciones, y sí pienso que la tecnología es ambigua, no tengo dudas que actores sociales conservadores del status quo conocen el efecto narcótico y desde esa conciencia lo reproducen) (Paul F. Lazarsfeld y Robert K. Merton, "Los medios de comunicación de masas, el gusto popular y la acción social organizada” 1969)

\section{La distancia con el prójimo y la “cercanía” con el lejano}

Paúl Virilio, en su obra “Cibermundo: una política suicida” escribió páginas notables respecto a la amenaza a la proximidad humana implicadas en las TIC. El autor francés ya en los noventa del siglo pasado reflexionaba sobre las consecuencias morales, políticas y culturales de la aceleración del tiempo mundial.

No puedo evitar una larga cita: «la ciudad ha sido siempre un dispositivo teatral: con el ágora, el atrio, el foro, la plaza de armas, etcétera... simplemente era un espacio donde se podía estar unido, es decir, un espacio público. Sin embargo, hoy el dispositivo tele reemplaza al espacio público por la imagen pública y la imagen pública es excentrada de la ciudad. La imagen pública no está en la ciudad, sino en la "tele-cittá", ciudad virtual en la que pretendemos cohabitar porque miramos juntos el telediario. Creo que lo que está en juego tras la cuestión del espacio virtual, es la pérdida de la ciudad real. (Hoy) se constituye la ciudad de las ciudades, la ciudad de las telecomunicaciones, la ciudad de Internet. Nuestras ciudades (reales) están en una situación catastrófica. No sólo Sao Paulo y Calcuta, sino también Washington y los suburbios de París, están hoy al borde de la implosión. La tendencia es hacia la desintegración de la comunidad de los presentes en beneficio de los ausentes -ausentes suscritos a Internet o presentes en la TV y los multimedios-. Se trata de un acontecimiento sin precedentes. Es uno de los aspectos del accidente general. El hecho de estar más cerca del que se encuentra lejos, que de aquel que está junto a uno (el 
prójimo o el próximo), es un fenómeno de disolución política de la especie humana. La pérdida del cuerpo propio conlleva la pérdida del cuerpo del otro, todo en beneficio de una especie de espectralidad de lo lejano, de aquel que está en el espacio virtual de Internet o en la ventanilla de la televisión”. (Virilio, Paul, 1997)

Es común que en nuestra sociedad de las TIC temamos y desconfiemos del cercano; mientras nos fascinamos, a partir de la apariencia, con aquel que está lejano y no conocemos. La Red y la TV como Plaza Pública es el paradigma mayor de esta realidad: hoy no es extraño que alguna gente reconozca en quienes aparecen en las mañanas, en las tardes y en las noches en su pantalla, ahí en el centro de su hogar, a personas supuestamente muy cercanas, como si fueran los antiguos vecinos de la plaza del vecindario, y en cambio ve como muy lejanos a sus próximos en el barrio. U otro ejemplo, la red social que es Facebook, una suerte de cofradía virtual de conocidos $-\mathrm{y}$ no tan conocidos- en interacciones cotidianas, que en muchos casos ha venido a reemplazar al antiguo y presencial grupo de amigos.

Cuántas veces nuestros hijos se ensimisman en el computador o en la TV y dejan de lado el juego físico y social; o bien cuántas veces dejan de observar el paisaje durante el desplazamiento en auto, mientras sí se conectan compulsivamente con cualquier aparato electrónico que les permita ingresar a un juego o a la red; o peor aún, una vez más atraídos por la conexión virtual, lisa y llanamente dejan de salir al campo, al mar o al parque sólo por el sereno placer de sentir la brisa y emocionarse con la luz. En suma, el estar obsesivamente conectados en esa suerte de océano virtual que es la comunicación o interacción a través de las TIC, cada vez más en el mejor de los casos tiende a inhibir y en el peor tiende a suspender la humana y profunda emoción del mirarse a los ojos o de emocionarse con la experiencia de la naturaleza.

Se requiere un difícil pero necesario equilibrio. Es potente y una maravilla las posibilidades de interacción relacional que posibilitan las TIC; pero es una sombra la distancia humana y del entorno natural que pueden también posibilitar en tanto sean irreflexivamente vivenciadas. Uno de los más interesantes desafíos que hoy nos plantean las TIC en la comunicación interpersonal y en la interacción con el mundo es precisamente recuperar la proximidad con el otro y con la naturaleza. Sólo en el encuentro cara a cara, en la relación personal, es posible mirarse a los ojos, sentir emociones y percibir, gracias a la cercanía, el sentido profundo de las interacciones. Y sólo en la experiencia de ver y sentir el mar, se puede asimilar la inmensidad y el misterio de la naturaleza.

\section{Pérdida de algunas habilidades sociales y éticas}

Muy relacionado con el punto anterior, es lo que podría estar ocurriendo a nivel neuronal en las nuevas generaciones, que nacieron con TV, video juegos y computador, y por eso son las que prefieren quedarse chateando en vez de ir a caminar a la playa o asistir a una reunión social. 
Según la neurociencia, la interacción directa y personal con el prójimo es un componente esencial, en tanto en esa interacción físicamente ocurre la sinapsis cibernética entre ser vivo -cerebro- y mundo, determinando un desarrollo temprano de las estructuras cerebrales y de las funciones cognitivas y empáticas. Estudios neurológicos recientes con las células espejos muestran que el sólo hecho de observar lo que hace otra persona afecta los nervios periféricos del observador y sus músculos específicos se activan. ${ }^{9}$

"Quizás desde que el hombre descubrió cómo usar herramientas, nunca como ahora el cerebro humano había sido afectado tan rápidamente por una tecnología” (Small, Gary, 2009). El planteamiento central de este neurocientista californiano es que a medida que el cerebro evoluciona y cambia su foco hacia nuevas habilidades tecnológicas, en paralelo va perdiendo habilidades sociales fundamentales, entre ellas la empatía, la compasión, la tolerancia.

Por eso, esta línea de investigaciones, que es cada vez más extendida, plantea como un desafío central que los padres interpelen a sus hijos, quienes son los más comunes usuarios acríticos de las TIC, y los eduquen invitándolos a alargar sus tiempos de desconexión de la tecnología, o lo que es lo mismo, invitándolos al encuentro social cara a cara, al goce de una caminata y del silencio.

\section{La ciber-pragmática y las limitaciones de contexto: error y horror interpersonal}

La comunicación interpersonal a través de las TIC, pese al fanatismo de los cien por ciento conectados, posee serias carencias y bemoles, causa de errores y horrores, que es necesario tener en cuenta para evitar la fascinación tecnológica acrítica.

La ciber-pragmática, según el investigador Francisco Yuz, se ocupa precisamente de las posibilidades del uso del lenguaje en el contexto de las nuevas tecnologías de comunicación virtual, a la vez que analiza las operaciones de contextualización que llevan a cabo los usuarios para interpretar los mensajes virtuales que reciben en su computador a través de la red... La diferente mediación del contexto en las situaciones cara a cara y virtual provoca diferentes resultados que deben ser explicados por esta pragmática orientada al estudio del lenguaje en entornos virtuales” (Yuz, Francisco, 2001a).

La ciber-pragmática enseña que la comunicación mediada por un computador (vía e mail, Chat, redes sociales) no suspende el hecho que "cada vez que un ser humano se comunica con otro, se activa en el destinatario, y en forma (biológica) automática, un proceso inferencial destinado a extraer del enunciado del emisor la información más interesante... (A pesar de los avances tecnológicos) el computador sigue sin poseer una competencia pragmática fundamental, es decir, una capacidad real para extraer información de múltiples fuentes contextuales y combinarla con el enun- 
ciado emitido para acceder a interpretaciones que a menudo divergen sobremanera de la información literal que dicho enunciado aporta... (En la comunicación mediada por las TIC) existe una importante merma en las posibilidades de contextualización y una limitación a la hora de generar la gama amplia de impresiones físicas compartidas por los interlocutores... (En suma)... lo que varía sustancialmente (si comparamos la comunicación cara a cara, que es integral, con la ciber-comunicación) es la accesibilidad a la información contextual que en la pragmática se ha revelado tan esencial para poder interpretar correctamente los enunciados en cualquier situación comunicativa” (Yuz, Francisco, 2001b).

Alguien podría argumentar -continúa Francisco Yuz- “que, por ejemplo, el conocido test de Turing, en el que un computador parece capaz de entablar una conversación, demuestra una cierta habilidad pragmática del computador, hasta tal punto que algunas personas incluso desconocen que están conversando con una máquina... Pero no olvidemos que las condiciones y la temática de la conversación están controlados por el investigador y en ningún caso se observa en dichas conversaciones una capacidad real de ironizar, bromear, aportar metáforas novedosas, usar hipérboles, etcétera... (Yuz, Francisco, 2001c).

Son cotidianas nuestras experiencias que dan cuenta de estas limitaciones pragmáticas de la ciber-comunicación. De ahí la superficialidad que muestran las TIC a la hora de intentar vía ellas el desarrollo de conversaciones más complejas, o bien el hecho cierto que tienden a la reducción o interrupción de la iniciativa comunicativa. Un ejemplo son los “peros” al uso abusivo de las TIC en las organizaciones, pues éstas sólo sirven para coordinaciones instrumentales y más que nada en el conocimiento explícito; sin embargo, no sirven ni para coordinaciones de equipos complejos ni menos para resolver temas propios del conocimiento blando (las tan fundamentales emociones, que hoy por la biología y ciencias cognitivas sabemos que están en la base de toda comunicación humana). Otro ejemplo, vivido por todos, es la cantidad de ruidos (horrores y errores) emocionales y comunicacionales que muchas veces generan los e mail y las redes sociales con sentidos mal entendidos o bien sacados de contexto.

En suma, desde la pragmática sabemos que la manera contextualmente más informativa de comunicación es la que los seres humanos establecen en situaciones de co-presencia física, cara a cara, que permite aprehender la denotación de la palabra, lo que connota la palabra, el tono, el gesto, el meta-gesto, la postura, la historia incluso del emisoroyente. Esto debería llevarnos a autolimitar la fascinación tecnológica, conscientes de la debilidad de las TIC (su escasa transparencia de contexto) que nos enseña la Ciber-pragmática.

\section{El mal de Matrix}

Muy relacionado a los puntos anteriores se encuentra la respuesta al por qué del desgaste emocional y el mal clima laboral que hoy se vive al 
interior de no pocas organizaciones. Las TIC habrían generado un nuevo "pecado en los líderes del siglo XXI: el mal de Matrix", según la sugerente imagen creada por Paloma Pérez Bravo, inspirada en el ya clásico del cine. (Pérez Bravo, Paloma, 2008). Claro que Pérez Bravo se autolimita en su análisis, pues el pecado no es sólo de los líderes, sino que esta sombra inunda a todas las relaciones interpersonales en las organizaciones e incluso en las familias y en las redes de amigos. Con este mal, mediante el abuso de las TIC, se elude o se resiente el difícil acto de la comunicación en los equipos de trabajo y/o en las relaciones interpersonales.

Atrapados en Matrix -y cito latamente el lúcido análisis de la profesional española- "nos convertimos en seres virtuales que nos manifestamos a través de mensajes de voz, correo electrónico, redes sociales o SMS. En Matrix, es posible comunicarse sin la necesidad de conocernos, sin la presión de miradas disconformes, réplicas incisivas o preguntas comprometedoras. En Matrix no es necesario dedicar mucho tiempo a la comunicación cara a cara. Pero Matrix no es todo. El líder -o las personas con este maltransforman su entorno en una fuente constante de conflictos...”.

Detengámonos sólo en su efectos en las empresas (en las redes sociales, hay otro tanto que reflexionar en esta línea): “el primer síntoma del mal de Matrix es la obsesión por estar "siempre online”; el segundo tiene su origen en que en Matrix “todo queda registrado”: el subalterno y su jefe, y los pares entre si, terminan manteniendo "conversaciones" -e mail- absurdos por el simple hecho de saber que ambos están guardando registro de todo lo hablado o escrito, bolas de nieve en forma de mails encadenados devoran poco a poco todo el tiempo productivo y las buenas relaciones del equipo..., pues la desconfianza campea a sus anchas en Matrix, perdiéndose el valor de aquel sencillo compromiso: "tienes mi palabra”; (otro) síntoma del mal ha de observarse en entornos donde reina la rumorología, ya que la (in)comunicación en Matrix, pese al exceso de información y flujos virtuales, es insuficiente a la hora de dar respuesta a las dudas del equipo, por ello el rumor busca reducir la incertidumbre en el entorno laboral”.

Una aclaración, ni Pérez Bravo ni quien escribe piensan que los seres humanos, y menos los líderes, no puedan utilizar las TIC para sentir y dejarse sentir. Es perfectamente posible, en tanto la ciber comunicación se asuma sólo como un complemento al imprescindible sentir presencial y físico. Con las TIC, ya lo sabemos, la información esta ahí a la mano, abunda para todos; pero, y también lo sabemos, la comunicación, si bien supone a la información, es más compleja, es el acto de dejarse sentir unos a otros.

Por eso, Pérez Bravo sugiere que salir de Matrix implica cambiar el estilo de dirección y el estilo de las relaciones interpersonales. Una cosa es seguir viviendo en el mundo de las TIC, pero otra es otorgar a la comunicación la relevancia y el tiempo que se merece. Lo que significa, entre otras recomendaciones para los líderes y usuarios de las TIC: conocer al equipo humano, a los pares y trabajar con ellos responsablemente; determinar reflexivamente lo que se quiere decir, cómo y cuándo decirlo; una vez ela- 
borado el mensaje, decidir el vehículo de transmisión y la fórmula que se va a emplear; prever las repercusiones y adelantarse para pronosticar reacciones; entender que no sólo comunican las palabras, sino que lo hacen nuestros actos, nuestra ropa, nuestros hábitos e incluso nuestra omisiones, todo comunica.

Como lo hemos escrito antes, desde el ingreso de las TIC a la deriva humana, no se puede hablar de lo "real" y lo virtual como dos ámbitos separados. No, lo realmente Real, valga la redundancia, es lo tradicionalmente real más lo virtual. Las TIC deben sólo ser usadas responsablemente, pues lo que facilita puede dificultar y lo que aproxima, puede distanciar. El gran error de todos quienes se contagian del mal de Matrix en las organizaciones y en las relaciones interpersonales es pensar que la virtualidad implica menos necesidad de esfuerzo y habilidades en la comunicación, cuando en la vida ocurre precisamente lo contrario: la virtualidad nos está exigiendo mayores habilidades para dejarnos sentir unos a otros.

En suma, si la comunicación es el hecho social fundamental (pues, parafraseando a Heidegger, los seres humanos moramos en el lenguaje), sin duda que la subversión de las TIC en las comunicaciones están impactando dimensiones existenciales e incluso biológicas del ser humano. Eso es lo que hemos tratado de exponer brevemente en este apartado (en esto, la reflexión y la investigación se encuentra en pleno desarrollo). Como observador confieso que lo hago fascinado ante la profunda ambigüedad de las TIC, de ahí sus luces y sombras, que muchas veces, como en la propia vida, se tocan en su profunda unidad y entonces advienen los matices. Las TIC nos acercan y nos alejan, las TIC informan y desinforman, las TIC despiertan y narcotizan, las TIC expanden la lectura y la limitan, las TIC promueven lenguajes y limitan lenguajes, y así. Por eso, como nos explayaremos en el epílogo, la relación con las TIC es un desafío a la responsabilidad y libertad humana (y en esto afortunadamente cada día emergen más ánimos y miradas críticas, nuevas prácticas y organizaciones que llaman a una relación más serena con las TIC).

\section{Ecos políticos y sociales de las TIC}

Si el impacto de las TIC es existencial, obviamente que además son la causa de una revolución, igual de ambigua en dominios de la política, la participación y lo social. Este impacto se aprecia en la gran política-social planetaria, en los Estados nacionales, a escala regional y local, y en las relaciones políticas en todas las organizaciones, en el sentido de las relaciones de participación y poder que se dan al interior de éstas.

\section{De Luces}

La Red democratiza la posibilidad de generar sentidos y la participación

Qué más revolucionario que por primera vez en la Historia Internet y las TIC puedan dotar a cada hombre y mujer y a cada colectivo u organi- 
zación, a través del despliegue de su libre creatividad, de la posibilidad de generar, emitir y estar simultánea e instantáneamente en todas partes con sus sentidos.

Asistimos a un escenario de democratización comunicacional inédito en la deriva humana. A nivel planetario y local, Internet permite que las organizaciones de la sociedad civil, los individuos, los artistas, los partidos políticos, las empresas, las escuelas, todos, puedan amplificar su voz. Se trata de la emergencia potencial de un nuevo orden horizontal con canales inmediatos para difundir información, comunicar y contactar con cualquier persona o institución del mundo, ya sea mediante la Web, el correo electrónico, la mensajería inmediata, los foros telemáticos, las videoconferencias, los blogs, las Wiki, las redes sociales.

Hoy prácticamente todos los movimientos sociales y ciudadanos utilizan Internet, más aún cualquier persona o activista puede en la Red convocar y coordinar a otros en torno a una iniciativa social. Con las TIC, por ejemplo, organizaciones locales acceden a un poder que les permite hacer denuncias con efectos globales: basta que un blog de denuncia ciudadana sea bien linkeado, con las alarmas y/o palabras correctas, para que se convierta de inmediato en una alerta de Google en todos los medios de comunicación. También con las TIC, organizaciones locales pueden potencialmente organizar protestas globales. Y lo mismo, a otra escala, puede ocurrir al interior de cualquier organización con sus respectivas redes internas.

Las TIC generan un nuevo tipo de comunidad on line. Con Facebook y otras redes Internet ha mostrado ser un ambiente altamente social, cuyas comunidades virtuales trascienden todo tipo de fronteras físicas. En ese marco, el concepto de Smart Mobs (Multitudes inteligentes) alude a "multitudes inalámbricas con capacidad de provocar movimientos de cambio social propios de una revolución” (Rheingold Howard, 2005).

Las TIC re-distribuyen el poder y abren oportunidades de participación cívica, social y política, además facilitan el funcionamiento de redes comunidades- cooperativas sobre la base de una democracia directa que promueve la resolución participativa de los temas. Las TIC facilitan en todos los niveles lo que hoy los teóricos políticos denominan el desafío de la Gobernanza en una sociedad social y culturalmente compleja, que es a la vez local y planetaria.

También las TIC impactan la gestión política representativa, ya sea en las naciones, en las comunidades locales y en las organizaciones, así como la gestión de los gobiernos, a través de lo que se conoce hoy como gobierno electrónico (E-gobierno o gestión de los servicios públicos on line) y la democracia electrónica (votación on line, acceso directo virtual a la Presidencia, Ministros o a las gerencias en el caso de las empresas). Internet potencialmente abre canales de información y de comunicación directos y retroactivos entre autoridades, funcionarios y ciudadanos. 


\section{La creación de conocimiento en las organizaciones}

Así como la Internet (Extranet) planetaria es un omnicerebro que potencialmente facilita la creación de conocimiento, en términos muy concretos la Intranet (la Internet acotada) en cualquier organización puede contribuir enormemente a la creación de conocimiento ad hoc a la respectiva organización. La Intranet, bien utilizada (neutralizando las sombras), supone una gran eficacia como herramienta de comunicación interna, pues puede contribuir a un mejor clima organizacional, personas más informadas, mayor motivación y productividad, aumento de la participación y una mejor respuesta ante situaciones de crisis en las organizaciones.

"Las intranet son sistemas complejos adaptables, es decir, sus agentes, léase, creadores, operarios y usuarios, realizan adaptaciones continuas en aras de mejorar el contexto informacional de la organización; sin embargo, aún cuando algunos agentes ganen de los cambios, el rendimiento del sistema total pudiera no mejorar”. (Dr. C. Melvyn Morales Morejón. M. Sc. María E. Carroteguas Rodríguez y Dr. C. Rafael Aviles Merens, monografía, 2008) Por eso, para que una intranet sea un buen sistema complejo adaptable y realmente potencie a una organización, es relevante que articule en su diseño y en su desarrollo dos criterios. Uno central, esto es que la red interna debe siempre aportar a la misión y procesos medulares según sea el tipo concreto y singular de organización de que se trate; y dos, otros criterios periféricos, aunque no menos relevantes, como lo son destacar aspectos institucionales, facilitar la creación de redes sociales en pos de la comunicación horizontal y vertical, hacia arriba y hacia abajo, incentivar la colaboración y el trabajo en equipo, ser fuente de respaldo para la socialización y enriquecimiento creativo de documentos y contenidos.

En ese marco, un rol clave de Intranet es su contribución a la creación de conocimiento: "las empresas (o cualquier organización) que son capaces de integrar eficazmente la percepción (del entorno), la creación de conocimiento y la toma de decisiones pueden ser descritas como una organización inteligente” (Sánchez González, Cesar Augusto, 2005).

En esto, hay una diferencia crucial entre las organizaciones de occidente y las de oriente. En occidente prima el conocimiento duro o explícito (técnico e instrumental, denotativo); mientras en oriente prima el conocimiento blando o tácito (intuiciones, trabajo en equipo, experiencia). El primero es más fácil de almacenar y transmitir, el segundo no. Las TIC, sin duda, tal cuál se usan hoy en occidente, llevan ventaja en la creación y mantenimiento del conocimiento explicito, sin embargo, podrían optimizarse aún más en el conocimiento tácito. A través del diseño y activación de redes sociales en las Intranet se podría favorecer más la gestión de este conocimiento, superando la práctica hoy hegemónica de redes internas que son simples "informativos electrónicos". Hoy muchos softwares posibilitan crear redes sociales internas, pero muy pocas organizaciones los utilizan, impidiendo la emergencia de redes en las que los usuarios de la intranet puedan crear sus propios perfiles y compartir creativamente. 


\section{De Sombras}

\section{Una tecnología alienante}

Junto a sus luces, las TIC conllevan sombras que hacen inciertos y desafiantes estos cambios políticos y sociales. En lo sustantivo, dos aspectos limitarían desatar las potencialidades democratizadoras de la tecnología comunicacional, uno que puede ser catalogado como sombra de las propias TIC, otro simplemente como condicionante de las propias organizaciones (sean Estados-naciones, regiones, ONGs y/o empresas).

Primero, la sombra: con el surgimiento de la radio y la TV y luego las TIC se abrió un debate entre los cientistas sociales respecto al proceso comunicacional en curso y su efecto en el ámbito político y social. En el extremo opuesto a la mirada que ve una oportunidad para la participación, teóricos ya mencionados como Merton y Lazarsfeld a finales de los sesenta describieron la (dis)función narcotizante de los Mass Media, que con las TIC hoy se ha agudizado. En esa misma línea crítica, otros analistas afirman que las TIC en rigor debilitan la acción ciudadana, pues los sujetos reemplazarían el encuentro cara a cara y el espacio público por el tiempo on line en el espacio virtual, e ingresar a redes sociales para ellos sería sinónimo de separatividad entre próximos y en consecuencia de inacción social colectiva. En suma, estos ven a la tecnología como factor de alienación, evocando así a la tradición intelectual que proviene de Marx en las ciencias sociales.

Segundo, el condicionante: otros observadores del proceso de participación abierto con las TIC, matizan afirmando que no serían estas las que modelan a la sociedad y/o las organizaciones, sino que son los rasgos identitarios y culturales profundos de las comunidades los que determinan como se utilizan las TIC. Si en una sociedad o colectivo hay conciencia política y tradiciones precedentes de movilización social, pues ahí Internet y las TIC actúan como un instrumento que potencia la acción y facilita el cambio social, pero no lo genera. Si en una empresa existe mal clima laboral junto a una cultura jerárquica y autoritaria, Intranet con seguridad se reducirá a un instrumento meramente informativo, despojándose de todas sus otras potencialidades comunicativas. Si un Estado o gobierno es débil y burocrático, las TIC serán usadas sólo para informar, sin retroalimentación. Es decir, en rigor la TIC sólo responderían a las características culturales más profundas del universo que las contiene. Sin duda que este condicionante de contexto opera como factor limitante o expansivo del rol democratizador de las TIC; no obstante, si hay un buen diseño de estas y líderes o grupos que en las organizaciones y/o comunidades promuevan el cambio social y/o una gestión del cambio cultural, siempre con las TIC se podrán activar canales comunicacionales democráticos y liberadores.

\section{La brecha socio-cultural digital y el impacto en el trabajo}

Como vimos en el apartado número dos, dada la desigual expansión, social y geográfica de las TIC, se ha generado una nueva brecha que 
incide en más exclusión social: la brecha tecnológica. Aunque los países pobres también incrementan su acceso a las TIC, los países desarrollados lo hacen mucho más rápido y en mejor calidad. Al interior de los países, la brecha tecnológica se reproduce entre núcleos urbanos y rurales y entre clases sociales. Ocurre entonces que la brecha digital simplemente replica y retroalimenta otras brechas existentes, aumentando así las diferencias entre distintos mundos.

También las TIC, con su automatización de procesos, han incidido en la reducción de puestos de trabajo (es más su impacto en el cierre de empleos que los que abre), lo que tiene profundos ecos sociales, por ejemplo, el drama de la cesantía o el Fin del Trabajo como hasta ahora lo habíamos conocido.

Por su parte, los territorios y sectores no conectados, a nivel global y nacional, pierden competitividad económica. Eso a nivel de colectivos, mientras que a nivel individual, quienes no tienen acceso ni competencias en las TIC son más débiles en el mercado laboral. En esto cobra relevancia tal vez un factor de brecha digital más importante que la conectividad técnica: la capacidad educativa y cultural de utilizar Internet. Saber buscar la información en la red, procesarla y convertirla en conocimiento útil, aprender a aprender, no es algo fácil, y en esto hay disparidad social y educativa, así como disparidad entre las generaciones jóvenes y adultas.

El desafío en todos estos frentes entonces es trabajar en la E-inclusión, es decir en el acceso a las tecnologías y la adecuación de éstas a las necesidades y especificidades de los colectivos más vulnerables, sean culturales (grupos migratorios y/o etnias diversas), económicos (pobres del campo o la ciudad, pequeñas empresas), sociales (sindicatos, organizaciones sociales y ciudadanas), así como en la alfabetización informática.

En superar esta compleja sombra hoy trabajan los países, la sociedad civil con sus ONG y empresas a través de sus políticas de inclusión y alfabetización digital.

\section{La irresponsabilidad ciudadana o funcionaria}

Así como la luz potencial de las TIC es activar la participación y el empoderamiento ciudadano y/o funcionario, también hay una sombra muy potente, que nace ya sea de los puntos ciegos de la tecnología o de la propia desidia o irresponsabilidad del usuario.

Es un punto ciego que a veces por la difícil identificación del interlocutor en la interacción virtual (al menos para un usuario sin competencias tecnológicas), las TIC ofrecen la ruin posibilidad del anonimato en el ciberespacio, lo que permite la impunidad de quién abusa del rumor o el comentario irresponsable.

Es inocultable desidia cuando a veces los usuarios - funcionarios delegan en el computador su responsabilidad en procesos complejos y/o 
que requieren pro-actividad humana. “Se cayó el sistema”, por ejemplo, es una respuesta muy común que seguramente usted lector ha escuchado a la hora de hacer algún trámite, negándose la contraparte a implementar cualquier solución alternativa. O bien, en especial en los procesos educativos, y resultado del fácil acceso y lo feble de la propiedad intelectual de los contenidos en Internet, hay un enorme espacio para el plagio intelectual. En suma, con las TIC sobrevienen una serie de desafíos éticos relacionados con la responsabilidad de nuestras acciones comunicativas en el ciberespacio.

\section{El riesgo de accidentes tecnológicos, globales y cotidianos}

Ya lo hemos dicho, el comercio, el intercambio financiero, la información estratégica y de seguridad, la regulación del transporte aéreo, marítimo y terrestre, público y privado, planetario y local, etcétera, pues casi todo es hoy regulado por las TIC.

No exageran entonces algunos autores que afirman que las nuevas tecnologías hoy constituyen el vehículo para un cierto tipo de accidente que ya no sería sólo local, como lo fue el naufragio del Titanic, sino que podría llegar a ser general. Y menciono la tragedia del Titanic porque afectó a miles de personas en un espacio acotado en el mar del Norte y que, según el filósofo y poeta Hans Magnus Enzensberger, puso simbólicamente fin al desvarío y la soberbia tecnológica de la modernidad (puso fin en el sentido que hizo perder la inocencia ante la técnica, esa fe e inocencia a lo Julio Verne).

Comparativamente hoy un accidente de las TIC podría involucrar inmediatamente a todo el mundo. ¿Qué ocurriría, por ejemplo, sí en Internet ocurriera un accidente con repercusiones integrales en lo económico, operativo y logístico en las redes mundiales? Tal situación no tiene precedentes en la historia.

Menos dramático, aunque más probable, es lo qué vemos cotidianamente con los eventuales riesgos de seguridad informática u operacionales, por ejemplo, con la posibilidad que se produzcan accesos no autorizados a los computadores de empresas y organizaciones de cualquier laya, el robo de los códigos de las tarjetas de crédito. Son todos accidentes tecnológicos que ponen una sombra en la eficiencia que también conllevan las TIC, lo que ha activado a la seguridad informática como un nuevo desafío en las organizaciones.

\section{El Big Brother}

Internet, como hemos dicho, desde el principio y hasta ahora se ha desarrollado como un instrumento libre de comunicación, a partir de una arquitectura informática de libre acceso y autogestionada, que ha sido progresivamente modificada sobre la base de una cooperación permanente de los usuarios más aventajados. 
Actualmente, sin embargo, tal como nos recuerda la filóloga francesa Bárbara Cassin en su libro Googléame, las direcciones del protocolo TCP/IP "son atribuidas y administradas por la ICANN (Internet Corporation for Assigned Names and Numbers), una organización sin fines de lucro de estatuto híbrido, semi-privada, semi-publica, ni realmente internacional ni realmente estadounidense. Cada computadora está identificada por una dirección IP que es algo así como su carnet de identidad. De esta manera se puede remontar de una pregunta a una computadora, y de una computadora a su comprador, hasta de un mail a su usuario, autor o destinatario...” Pues bien, de esa descripción respecto a cómo opera el sistema “...procede el temor perfectamente justificado de que un Big Brother si quiere pueda saberlo "todo", vale decir, a condición de encontrarle interés y tomarse el trabajo” (Cassin, Bárbara, 2008). En suma, en Internet no existe la privacidad, en la Red todo puede ser rastreado a través de programas expertos.

En esta misma línea, en su última obra El Futuro de Internet, el abogado de Harvard, Jonathan Zittrain, experto en regulaciones cibernéticas, alerta respecto a qué Internet, con su frágil, libertaria y cooperativa arquitectura, podría desaparecer, tendiendo a sobrevalorar la seguridad y así limitar la privacidad. ¿Por qué? "Porque el comunitarismo, junto a sus fortalezas creativas, tiene un costo: virus, programas que colapsan los navegadores, robos de contraseñas y de números de tarjetas de créditos, acoso cibernético y el insoportable spam, que según Zittrain, hoy constituye el $90 \%$ de todos los e-mails que circulan en el mundo. Los malos se aprovechan de la misma arquitectura que los buenos. Como respuesta a eso, compañías como Apple, con ¡Phone, por ejemplo, tienen su "propio" Internet: una red que conecta a millones de personas, en la que el código esta debidamente autorizado por los propietarios de la red y los usuarios no contribuyen al desarrollo de esas redes. No hay creatividad en iPhone a menos que Apple, la compañía madre, la encargue o apruebe. Y si progresivamente la red se mueve hacia la seguridad y eficiencia de iPhone, y abandona la creatividad y libertad del PC, lo más lógico es que ocurra lo mismo a lo largo y ancho de ella. De hecho progresivamente la red avanza hacia un "lugar" que los teóricos digitales y los desarrolladores de programas han denominado La nube: todo aquello que hoy hace el PC, lo puede hacer la nube. Por ejemplo, una función tan simple como almacenar documentos, hoy la puede realizar un servicio en red como Google docs...” “...Zittrain argumenta que no es enemigo de "la nube”, pero reivindica la necesidad de dar continuidad a mentes que colaboren en un ethos de buena onda para solucionar un problema. Tal como lo han hecho los desarrolladores de código para Internet a lo largo de todos estos digitales años” (Sepúlveda, Alfredo, 2009).

También Big Brother puede levantar barreras, por ejemplo, la nueva muralla que el gobierno chino ha construido en el seno de Internet, censurando los sitios de opositores o las informaciones e imágenes que no le convienen, ha terminado por reducir a Internet a una enorme Intranet acotada a China- que es políticamente correcta. O recientemente, como ya 
indicamos, la reacción y persecución global del poder, desde Estados Unidos a China, con todos los Bigs Brothers del mundo uníos para sancionar y tratar de excluir de la Red a Julian Assange y su sitio WikiLeaks por informar "asuntos privados" que paradojalmente nos impactan a todos.

Todo eso en Extranet, en la Intranet de cualquier organización esta sombra es aún más próxima, Big Brother podría llegar a ser un anónimo funcionario del área de Tecnología Informática que lisa y llanamente decidiera tentarse con el control o atentar contra la privacidad de los funcionarios.

En suma, en la esfera político - social las TIC han llegado para quedarse con una serie nada trivial de desafíos. Nuevamente se trata de vivir, comprender y optar en la ambigüedad inherente a sus luces y sus sombras, ya sea en el ejercicio de la democracia y la participación ciudadana, en la ética y la responsabilidad, en aspectos de seguridad y ante eventuales accidentes tecnológicos generales, en nuevos desafíos de inclusión y equidad social, entre los más relevantes.

\section{A manera de epílogo}

Para concluir, algunas reflexiones que de una manera u otra subyacen en el intento de este ensayo por resumir y describir la rica ambigüedad de las luces y sombras de las TIC.

Como lo he sugerido una y otra vez, nuestro actual desafío cultural es superar el sentido común que tiende a pensar en las creaciones tecnológicas como algo dado per se, ante lo cuál sólo hay que caer rendido y fascinado. Pues, eso es precisamente la dependencia tecnológica: la creencia que las TIC solucionarán todos nuestros problemas de comunicación y el mito que serían inocuas, sin sombra. Mitificar una tecnología es peligroso porque entonces se le acepta acríticamente, renunciando así a nuestra libertad, ya que se niega la posibilidad de modificarla o bien se soslaya el debate acerca de un uso responsable de la técnica. La ética nos orienta cómo debemos actuar en relación a los demás; la tecno-ética nos debería orientar en la relación entre las opciones tecnológicas, sus usos y sus consecuencias éticas.

Es una decisión ética cotidiana optar en la compleja ambigüedad que conllevan las luces y las sombras de las TIC que hemos enumerado de manera provisoria y descriptiva en este ensayo. Y es una decisión individual porque además lo que para un sujeto puede ser una luz para otro puede ser una sombra (un ciudadano autoritario seguramente sufre con las opciones de participación que abre Internet, para él es una sombra, mientras que para un ciudadano libertario esa potencia son las luces de la red). Y es una decisión colectiva regular el uso de las TIC, regulación que en última instancia es problematizar socialmente y definir que entenderemos mayoritariamente por luces y sombras, luego qué queremos, más luces o 
más sombras, e incluso como regulamos las luces y como minimizamos las sombras. En eso se abren desafíos políticos y sociales, legales y de fiscalización y acción ciudadana.

En lo existencial quiero afirmar que nuestro actual desafío cultural más profundo radica en optar entre el Bien o el Mal de Matrix. Recordemos que en sus implicancias filosóficas y éticas, la saga fílmica ya de culto, nos interpelaba como humanidad -a través del viaje espiritual de Neo- con la siguiente disyuntiva: u optamos por el frenesí tecnológico y alienado de los ciegos conectados (el Mal de Matrix), u optamos por el sentido humano de la libertad y el conocimiento integrado de lo Real, que incluye lo virtual y lo no virtual (el Bien de Matrix). Ahí, en esa opción, entre aceptar o no la pastilla que en el primer film de la saga Morfeo ofrece a Neo, hay una metáfora en la que se juega la libertad humana.

La opción de no aceptar la pastilla, que es el camino del Mal de Matrix, resuena en este diálogo notable entre Morfeo y Neo:

“- Morfeo: Tienes que entender que la mayoría de las personas no están preparadas para ser desconectadas. Muchos de ellos están tan inertes, son tan desesperadamente dependientes del sistema (léase las TIC) que lucharan para protegerlo... Matrix esta en todas partes... es el mundo que ha sido puesto ante tus ojos para ocultarte la verdad.

- Neo: ¿Cuál es la verdad?

-Morfeo: Eres un esclavo (conectado)”.

Mientras que la opción de tomar la pastilla, que es el camino del Bien de Matrix, abre otro mundo: el del tan humano desgarro del ser ante la tecnología. Al respecto, en el segundo filme de la saga hay una poderosa conversación entre Neo y el anciano consejero de Sión (el lugar donde los humanos se han retirado ante el creciente dominio de las maquinas). En ese diálogo, ya veremos que con ecos Heideggerianos, el sabio consejero invita a Neo (nos invita) al desasimiento humano de la técnica, luego de revelar lo intrincado e inherente de la relación entre la técnica y el ser en toda cultura. Además, toda la saga juega con la paradoja que los más sofisticados usuarios de la tecnología son a la vez los rebeldes y libres humanos que luchan contra las máquinas: no olvidemos que Neo, Trinity y Morfeo, por ejemplo, son hackers.

Se trata de un desafío cultural nada trivial, que además no sólo tiene que ver con las TIC, sino que incluyo a la biotecnología, a la nanotecnología, a la energía nuclear. Es el desafío que nos impone el macro poder tecnológico planetario que hemos construido. La técnica, lo hemos reiterado, es un hecho que emerge de la libre creatividad humana. En el acto de crear la técnica (praxis) se expresa el talento y el asombro, en ella, si se quiere, se expresa la libertad del espíritu humano. Mientras, en el acto de usarla, por tratarse de la propia prolongación humana, la técnica condiciona nuestro vivir en una intensa dinámica existencial. En síntesis, dialécticamente en el 
uso de la técnica se juega entonces la misma libertad creativa que nos permitió crearla.

Nuestro desafío nos impone trascender la actual comprensión de la técnica como un fetiche (y uso aquí el concepto fetiche como sinónimo de un ídolo, como algo que nos domina, como lo menos parecido a la libertad, idea que a propósito de la emergencia de la conciencia de separatividad -y la libertad que conlleva- desarrolló de manera extensa y muy bellamente el filosofo y sicoanalista Erich Fromm en su obra "Seréis como Dioses: un análisis de la génesis del monoteísmo”). Y la actual fetichización o fascinación acrítica ante la técnica sólo será trascendida una vez imbuidos de serenidad y desasimiento en el trato cotidiano de cada hombre y mujer al relacionarnos sea con las TIC como con cualquiera de las actuales maravillas tecnológicas que hemos creado.

\section{Un cambio en nuestra relación con la tecnología: es necesaria la serenidad}

Inspirado e inspirador, visto desde hoy, fue el sentido profundo y simple de la invitación que a mediados del siglo XX nos hiciera el filósofo alemán Martín Heidegger para revincularnos con desasimiento y serenamente con la técnica (La tesis Heideggariana acerca de la técnica. Borges Duarte, Irene). Las tecnologías, a estas alturas del ensayo ya lo sabemos, son resultado de la deriva de lo humano e imponen ineludibles cambios en la cultura. A la vez, recursivamente, cada cultura humana puede y debe reflexionar sobre sus vínculos con la tecnología.

Las nuevas tecnologías postmodernas -Internet, la Biotecnología y la Nanotecnología- han sido un bello resultado de la racionalidad instrumental moderna, cuya expansión originaria fue inspirada por la fe en un progreso indefinido de lo humano (ambos paradigmas hoy cuestionados). Hoy el agotamiento de los paradigmas del progreso y de la racionalidad instrumental coincide con el amenazante macro-poder de las nuevas tecnologías posmodernas que paradójicamente se han incorporado a nuestro vivir para incentivar una ruptura con la propia lógica tecnocrática de la modernidad. Hoy son ellas mismas, con su singular poder y con sus riesgos de accidentes generales y de presión hacia la insustentabilidad social y emocional, las que nos exigen un cambio cultural en la manera de vivirlas.

En otros ensayos he afirmado que así como la tecnología del carbón, de la red de tranvías, de la imprenta y de la electricidad fundó a la sociedad moderna e industrial, hoy las nuevas tecnologías, en tanto se vivan con serenidad, podrían contribuir a crear la sociedad posmoderna. La nueva tecnología postmoderna, junto a su macro poder eventualmente destructivo, se caracteriza no sólo por extender nuestros sentidos y nuestros cuerpos, sino lo nuevo es que ahora también son capaces de crear nuevos sentidos y nuevos cuerpos, por ejemplo, a través de las TIC y la Biotecnología. (Dinamarca, Hernán, 2004) 
El devenir del modo de vida postmoderno dependerá de la reflexividad y sabiduría que apliquemos en todas nuestras necesarias innovaciones tecnológicas, o, dicho en clave de interrogante, dependerá de la manera como nos relacionemos con la tecnología: si la continuamos fetichizando a la manera moderna — nos fascinamos acríticamente- o bien la asumimos con serenidad, responsabilidad y desasimiento.

En ese mismo ánimo reflexivo y emocional, el Premio Nacional de Ciencias en Chile, Humberto Maturana nos recuerda que el actual "Homo sapiens técnico", típicamente moderno, endiosa la tecnología, la usa para destruir la naturaleza y a nosotros mismos y tiene una relación acrítica con la misma, de ahí que él promueva la emergencia cultural de un nuevo "homo sapiens amoroso", postmoderno, que sepa derivar con su poder tecnológico en concordancia con la naturaleza. ${ }^{10}(10)$.

Esta tensión cultural en el presente como Historia respecto a cómo relacionarnos con la técnica (si en desasimiento o en fetichización) es bastante evidente en simples gestos de la vida cotidiana. Reiteramos ejemplos: hoy es cada vez más común que las TIC sean usadas por algunos individuos de manera acrítica (en especial por las nuevas generaciones, cuando lo hacen bajo la mirada pasiva de los padres), en una conexión virtual y casi obsesiva en su permanencia: estar "conectados es estar siempre en el ciberespacio" se dice; pero sobre la base de ese uso obsesivo e individual, paradójicamente, Internet termina siendo una red de (in) comunicación que interrumpe la "antigua” comunicación cara a cara y con ellos nuestro mundo más afectivo y cercano. En oposición, y desde una tesitura más serena, también es posible vivenciar con desasimiento a Internet. Es decir, usar la Red cuando sea necesario para auto potenciarnos con sus maravillosas posibilidades de interconexión, como si ésta fuera una red neuronal planetaria; pero sin que le inhiba a uno lo propiamente constitutivo de lo humano: el afecto y la emoción de la comunicación cara a cara, el encuentro personal.

En el mundo existe debate público al respecto porque ya son muchos los que viven sólo con la Red y solos en la Red, casi auto condenados a ser «amebas» en una celda, sin cercanía física con el otro (es cosa que cada uno en nuestro entorno cercano observemos el comportamiento de algunos usuarios en Facebook), dejando de lado la muy humana proximidad. En este último comportamiento, obviamente, no hay serenidad; de esa manera nos acercamos a la pura espectralidad sobre la que nos alerta Paúl Virilio.

Con todo, y tal vez por designio de un elemental instinto emocional de supervivencia, cada día más se sistematiza reflexión crítica, nacen organizaciones ciudadanas que promueven una nueva relación libre y serena con las TIC y cada día más los propios usuarios están revalorizando la proximidad: esto es el inestimable e irremplazable valor del encuentro cara a cara, con toda la vitalidad emocional que trae el complejo lenguaje humano a cuestas. 


\section{Un re-pensar la comunicación humana}

Junto a la revolución que implican las TIC, como telón de fondo hoy asistimos a un cambio relevante en la manera de hacer y experienciar la comunicación. Durante los últimos siglos, al menos en occidente, la comunicación entre seres humanos se comprendía en un solo sentido -de emisor a receptor- y se pensaba y se quería racional, rígida, objetiva.

La palabra era supuestamente un «instrumento objetivo», usado por una racionalidad separada y totalitaria con el fin de develar la verdad en y del mundo. De esa comprensión se desprendía el gesto autoritario, la rigidez comunicativa de la jerarquía, la frialdad emocional y la confianza torpe en que lo que se decía debía ser entendido literalmente, sin ambigüedad. Así se creía y así se proponía en el seno de las comunidades humanas de todo tipo, desde la familia, pasando por las empresas hasta los estados, generando eficiencia en algunos casos, pues el autoritarismo y el orden a veces lo es, pero también generando mucho dolor emocional.

En cambio, desde los años 60 del siglo XX, en el seno del emergente nuevo paradigma social postmoderno históricamente constructivista ${ }^{11}$ se empieza a comprender la cultura como una red de conversaciones y a la comunicación humana como un "lenguajear" histórico de razones que ordenan la experiencia y sentimientos y emociones. La palabra simplemente constituye el mundo y se viste con la misma y vital riqueza y ambigüedad del mundo.

Por eso, en las últimas décadas se ha re-significado la comunicación interpersonal, asumiendo que esta es siempre de doble vía, que emisor y receptor son roles intercambiable en el mismo acto de la comunicación, son indivisibles. Se ha re-significado la importancia de la escucha activa en las relaciones interpersonales. Se ha re-significado a la colaboración como elemento constitutivo de lo humano (precede a la competencia) y la presencia fundamental de las emociones en toda experiencia comunicativa, lingüística o no. Se ha re-significado en toda su radicalidad que en toda interacción humana las palabras denotan y connotan.

Hoy son muchas y diversas las reflexiones desde la academia -con la consecuente transferencia práctica a las organizaciones en todo el mundo-, que están enriqueciendo y debatiendo esta nueva manera de entender la comunicación humana. Por eso, en las organizaciones se multiplica la capacitación en el manejo de las emociones; el coaching para un liderazgo inclusivo y democrático; el entrenamiento en el trabajo en equipo; la capacitación en el concepto de red de relaciones; el entrenamiento en la importancia de la influencia y la seducción, en desmedro de la imposición.

Y en este proceso las TIC son potencialmente grandes aliadas, en tanto sean utilizadas serenamente, superando la acrítica fascinación tecnológica y asumiendo la importancia de no perder la proximidad. Así, sólo así, podremos superar la actual sociedad de la información, una triste so- 
ciedad en la que vivimos inmersos en grandes cantidades de bits - información, pero que nos están dejando fríos e incomunicados, cada día menos sabios y más solitarios, lejanos, como espectros que nos reflejamos en los computadores sin que ninguna Alicia se reconozca en el otro que subyace tras esa suerte de espejo solipsista que son las pantallas. Pues, como antes en la deriva humana, solo emocionados junto al próximo podremos ahora transitar hacia una sociedad realmente del conocimiento, como lo podría ser aquella en que serenamente nos iluminemos con las luces de las TIC. 


\section{Notas}

${ }^{1}$ Comunicación es igual a communicatio, comunis, poner en común, significa sentirse unos a otros. Según Corominas, el concepto aparece en 1.440, derivado del latín "Communicare" que “en la baja época se emplea con el sentido de comulgar”. En 1.220-50 se origina la palabra "comulgar" con el sentido de "dar o recibir la sagrada comunión” y en 1.440 se usa con el sentido de "compartir".

${ }^{2}$ Como lo he expuesto latamente en otros ensayos, en los años sesenta del siglo XX hubo muchas innovaciones tecnológicas y culturales. Por nombrar sólo algunas, el hombre llega a la luna, se inventa la píldora anticonceptiva, se observa por primera vez la radiación cósmica del Big Bang, se crea Internet, en biología se descubren los telómeros, la teoría de Gaia y las primeras formulaciones de la teoría de la autopoiesis... También en esos años se inician cambios culturales que se insinúan como "marginalidades dinámicas”, según la feliz expresión del pensador francés Félix Guattari: movimientos sociales y culturales que surgen en las orillas del sistema social, pero que tienden históricamente a expandirse hasta convertirse en nuevos modos de vida. Ese ha sido el proceso de los movimientos contraculturales de los sesenta: ahí surgen los ecologistas; las feministas contemporáneas; los movimientos en pro de la tolerancia y la legitimidad del otro, de la aceptación de las identidades y diversidades sexuales, culturales y étnicas; los primeros signos de una nueva economía y la actitud cultural de la individuación y el desarrollo personal. Y quién puede negar que la sensibilidad implícita en esas marginalidades dinámicas, hoy son una nueva red de conversaciones.

${ }^{3}$ Forrester Research, Inc. (Nasdaq: FORR) es una compañía de investigación y prospecciones de futuro en tecnología. Su sede central se encuentra en Cambridge, EE.UU.

${ }^{4}$ El Informe de Desarrollo Humano (IDH), elaborado por el PNUD, desde 1990 es un indicador estándar que se aplica en todo el mundo. El IDH tiene por objetivo medir el grado de avance de desarrollo humano -integral, socio, económico y educativo- en un espacio geográfico y territorial dado, generalmente países.

${ }^{5}$ Menciono aquí sólo a algunos autores, a quienes tengo un especial afecto. Entre otros, Jeremy Rifkin, Morris Berman, Humberto Maturana, Francisco Varela, Fritjof Capra, Brian Swimme, Ken Wilber y Edgard Morin, desde sus respectivos campos develan que asistimos a un cambio de época. En lo personal tengo la convicción que en el presente como Historia vivimos un proceso transicional que desde hace años vengo denominando una Neo-ilustración por su analogía con el proceso acaecido en los siglos XVII y XVIII. Pues así como esos siglos constituyentes de la modernidad fueron animados por el movimiento intelectual y creativo de la Ilustración, que ayer actuó como un nuevo paradigma social moderno y subversivo ante lo que era la agotada cosmovisión del mundo feudal-monárquico, las décadas post-sesenta del siglo 20 y las próximas décadas del siglo XXI están siendo y estarán animadas por el devenir creativo, diverso y fértil de un proceso de Neo-Ilustración que es portador de nuevas ideas y prácticas del paradigma social postmoderno históricamente constructivista (llámese paradigma sistémico, en red, ecológico, holístico, como sea). Este ha venido subvirtiendo desde sus raíces el ya antiguo y agotado modo de vida y cosmovisión moderna, siendo construido por una pléyade de autores que provienen de distintos ámbitos, que incluso a veces parecen -o se asumen como contradictorios- pero que están unidos por una común criticidad a una modernidad en retirada.

${ }^{6}$ Varios cientistas sociales contemporáneos han reflexionado sobre este desplazamiento, 
desde la sociedad agraria, pasando por la industrial hasta arribar a la sociedad informática o pos-industrial o posmoderna. Paúl Virilio, Rafael Echeverría, Anthony Giddens, por nombrar sólo a algunos.

${ }^{7}$ Para quienes se interesen en este debate técnico en Wikipedia hay una síntesis bien informada.

${ }^{8}$ Una reflexión más amplia sobre este tema se encuentra en mi ensayo: Optimismo de la Inteligencia, pesimismo por la voluntad (ver en otros escritos en www.hernandinamarca.cl)

${ }^{9}$ En su libro La Civilización Empática (ver bibliografía), Jeremy Rifkin dedica un capítulo extraordinariamente informado y sucinto respecto a los avances de la investigación en neurociencias entre la fecha del descubrimiento de las neuronas espejos, a inicios de los noventa, hasta el 2009, mostrando la profunda relación entre estas y la emoción empática.

${ }^{10}$ Ver entrevista que hice a Humberto Maturana en libro Bolero de Almas, conversaciones de Fin de siglo con Viejos sabios. Lom, 1996.

${ }^{11}$ El concepto posmoderno históricamente constructivista es de mi autoría. En el libro Epitafio a la Modernidad hay un desarrollo extenso del mismo. Claro que en rigor el concepto se inspira en la expresión Posmodernos Constructivistas creada por David Ray Griffin, teológo y filósofo norteamericano, con el fin de nominar y así diferenciar a aquellos autores posmodernos que no se limitaban al desconstructivismo -a la manera francesa-, sino que proponían y construían una nueva mirada. Lo que hice fue agregarle la expresión «históricamente» con el fin de marcar el sentido histórico de la construcción de una nueva mirada o nuevo paradigma crítico y superador de la mirada de la modernidad. La posmoderno históricamente constructivista es el movimiento creativo que se despliega en praxis -nuevas ideas y acciones- en el actual proceso de Neo-ilustración al que hacía referencia en la nota número 5. Y por ello como concepto lo considero importante y lúcido para comprender y participar en la reflexión y acción en el presente como Historia. 


\section{Bibliografía}

Borges Duarte, Irene, La tesis Heideggariana acerca de la técnica. Universidad Complutense, España. Disponible en http://revistas.ucm.es/fsl/ 02112337/articulos/ASHF9393110121A.PDF

Cassin, Bárbara (2008), Googléame, La Segunda Misión de los Estados Unidos, Fondo de Cultura Económica.

Dinamarca, Hernán (2004), Epitafio a la Modernidad: desafío para una crítica posmoderna, Ediciones Universidad Bolivariana, Santiago de Chile.

El futuro de Internet, vídeo. Disponible en http://www.youtube.com/ watch?v=BnUhZ57fwbI

Enzensberger, Hans Magnus (s/d), El Hundimiento del Titanic, un poema épico, Editorial Anagrama.

Fromm, Erich (s/d) Seréis como Dioses, Paidos Ibérica.

Lazarsfeld, Paul y Merton, Tomas K., Comunicación de Masas, http:// www.mexicodiplomatico.org/lecturas/Comunicacion\%20de\%20masas.pdf

Margulis, Lynn y Sagan, Dorion (1992), La danza Misteriosa de la Vida. Rústica. Kairos 1992.

Mayans i Planells, Joan (2002), “Metáforas Ciborg. Narrativas y fábulas de las nuevas tecnologías como espacio de reflexión social”. Fuente Original: Josep M. Esquirol (ed.), Tecnología, ética y futuro. Actas del I Congreso Internacional de Tecnoética, Desclée, pp. 521-534, Bilbao. Disponible en el Archivo del Observatorio para la CiberSociedad en http:// www.cibersociedad.net/archivo/arTICsulo.php?art=24

Morales Morejón, M.; Carrodeguas Rodríguez, M.E. y Avilés Merens R. Las intranets en la gestión informacional: un escalón imprescindible en la búsqueda del conocimiento organizacional. Acimed 2004; 12(3). Disponible en: http://bvs.sld.cu/revistas/aci/vol12_3_04/aci03304.htm

Pérez Bravo, Paloma (2008), "El mal de Matrix o la Comunicación del líder”, Revista Capital Humano, edición para Chile, octubre 2008.

Postman, Neil (2004), “Las cinco advertencias del cambio tecnológico”. En Economía y Desarrollo, portal de globalización. Disponible en http:// www.globalizacion.org/desarrollo/Postmancambiotecnologico.htm

Rheingold, Howard (2005), Las Multitudes Inteligentes: La próxima revolución Social, Gedisa Editorial. 
Rifkin, Jeremy (2010) La Civilización Empática, Paidós. $1^{\circ}$ edición en español, marzo 2010.

Sánchez González, César Augusto (2005), «Creación de Conocimiento en las Organizaciones y las Tecnologías de Información como Herramienta para alcanzarlo». Original. En ARCHIVO del Observatorio para la CiberSociedad, en http://www.cibersociedad.net/archivo/articulo. php?art=211

Sepúlveda, Alfredo, comentario al libro El Futuro de Internet de Jonathan Zittrain. Disponible en http://www.observatoriofucatel.cl/la-nube-sobreinternet

Small, Gary (2009), El cerebro digital: como las nuevas tecnologías están cambiando nuestra mente, Urano.

Virilio, Paúl (1997), Cibermundo: ¿Una política Suicida? Conversación con Philippe Petit, Dolmen Ediciones.

Yus, Francisco (2001), Ciberpragmática: entre la compensación y el desconcierto. Disponible en archivo del Observatorio para la CiberSociedad http://www.cibersociedad.net/archivo/articulo.php?art=42

Recibido: 28.04.2010

Aceptado: 24.11.2010 